九州大学学術情報リポジトリ

Kyushu University Institutional Repository

Effects of Elevated Irradiance, Temperature, and Rapid Shifts of Salinity on the Chlorophyll a Fluorescence (0JIP) Transient of Chattonella marina var. antiqua

QIU, Xuchun

Institute of Environmental Health and Ecological Security, School of the Environment and Safety Engineering, Jiangsu University

WU, Min

Department of Environmental Sciences and Industrial Development, Faculty of Postgraduate Studies for Advanced Sciences, Beni-Suef University

MUKAI, Koki

Laboratory of Marine Environmental Science, Faculty of Agriculture, Kyushu University

SHIMASAKI, Yohe i

Laboratory of Marine Environmental Science, Faculty of Agriculture, Kyushu University

他

https://doi.org/10.5109/2340991

出版情報：九州大学大学院農学研究院紀要. 64 (2)，pp.293-300，2019-09-02. Faculty of Agriculture, Kyushu University

バージョン：

権利関係 : 


\title{
Effects of Elevated Irradiance, Temperature, and Rapid Shifts of Salinity on the Chlorophyll a Fluorescence (OJIP) Transient of Chattonella marina var. antiqua
}

\author{
Xuchun QIU ${ }^{1 *}$, Min WU' ${ }^{1}$, Koki MUKAI, Yohei SHIMASAKI and Yuji OSHIMA \\ Laboratory of Marine Environmental Science, Faculty of Agriculture, Kyushu University, \\ Motooka 744, Nishi-ku, Fukuoka City, 819-0395, Japan \\ (Received May 7, 2019 and accepted May 8, 2019)
}

\begin{abstract}
Chattonella spp. often experience a broad variety of environmental changes in coastal areas. However, insights into their stress responses to shifts of environmental factors remains largely unknown. In this study, we investigated responses in the OJIP transient of C. marina var. antiqua grown under various culture conditions. Short-term irradiance shifts experiment showed that a 4-h exposure to elevated irradiance (EI, $1100 \pm 50 \mu \mathrm{mol}$ photons $\mathrm{m}^{-2} \mathrm{~s}^{-1}$ ) significantly decreased the $\mathrm{F}_{\mathrm{v}} / \mathrm{F}_{\mathrm{m}}$ ratio, $\mathrm{PI}_{\mathrm{ABS}}$, and $\mathrm{ETo} / \mathrm{RC}$, while increased the $\mathrm{ABS} / \mathrm{RC}, \mathrm{TRo} / \mathrm{RC}$, and $\mathrm{DIo} / \mathrm{RC}$ of Chattonella cells. When the cells were shifted back to the control irradiance (CI, $110 \pm 10 \mu \mathrm{mol}$ photons $\mathrm{m}^{-2} \mathrm{~s}^{-1}$ ), all the above parameters recovered to normal status within $3 \mathrm{~h}$. During batch cultures, repeated irradiance shifts (exposure to EI for $4 \mathrm{~h}$ per day) significantly decreased the maximum cell densities of $C$. marina var. antiqua (to $64 \%$ of that in control), but did not affect the maximum growth rate. The decrease of $\mathrm{PI}_{\mathrm{ABS}}$ could recover to normal status at the next morning at the exponential phase, suggesting the importance of weak light intensity in morning and evening for the recovery from photoinhibition and consequent algal growth in actual environment. But $\mathrm{PI}_{\mathrm{ABS}}$ level did not completely recover at the stationary phase. The interaction of temperature and rapid salinity shifts played significant roles in mediating growth rate, $\mathrm{F}_{\mathrm{v}} / \mathrm{F}_{\mathrm{m}}$ ratio, and $\mathrm{PI}_{\mathrm{ABS}}$ of $C$. marina var. antiqua. Despite water temperatures, rapid salinity shifts from 30 to 10 tended to notably decrease growth and photosynthetic activity of C. marina var. antiqua.
\end{abstract}

Key words: Chattonella marina var. antiqua; irradiance shifts; Chlorophyll $a$ fluorescence transient (OJIP); photosynthesis, salinity shifts

\begin{abstract}
ABBREVIATIONS: ABS/RC: light absorption per active reaction center; DIo/RC: dissipation energy per active reaction center; ETo/RC: the electron transport per active reaction center; $\mathrm{F}_{\mathrm{v}} / \mathrm{F}_{\mathrm{m}}$ ratio: maximum quantum yield of Photosystem II; OJIP: chlorophyll a fluorescence transient; $\mathrm{PI}_{\mathrm{ABS}}$ : performance index on absorption basis; PS: photosystem; $\mathrm{Q}_{\mathrm{A}}$ : primary quinone; RC: reaction center; TRo/RC: trapping of excitation energy per active reaction center
\end{abstract}

\section{INTRODUCTION}

Over the past several decades, raphidophytes Chattonella spp. have frequently formed harmful algal blooms (HABs) and caused serious ecological damages and economic losses in the coastal waters around the world (Imai and Yamaguchi, 2012; Pérez-Morales et al., 2017; García-Mendoza et al., 2018). Because a massive increase in cell number is essential for the occurrences of Chattonella HABs, numerous studies have been conducted to investigate the effects of ambient factors on their growth and bloom ecology (Imai and Yamaguchi, 2012). In general, the irradiance, water temperature, salinity, and nutrients are the most significant factors for the growth and their bloom formation of Chattonella spp. (Nakamura, 1985; Yamaguchi et al., 1991; Yamatogi et al., 2006; Katano et al., 2012; Katano et al., 2014), while some biological factors also play important roles in affecting their bloom dynamics (Qiu et al., 2011; Qiu et al., 2014; Park et al., 2016).

On the other hand, HABs species may undergo rapid

${ }^{1}$ Institute of Environmental Health and Ecological Security, School of the Environment and Safety Engineering, Jiangsu University, Zhenjiang, Jiangsu 212013, P. R. China

* Corresponding author: e-mail: xuchunqiu@agr.kyushu-u.ac.jp (X. Qiu) shifts of environmental factors, especially in the coastal areas. For example, the irradiance of surface water can increase from 0 to $>1000 \mu \mathrm{mol}$ photons $\mathrm{m}^{-2} \mathrm{~s}^{-1}$ within 8 hours in summer (Marshall and Hallegraeff, 1999), and the salinity of surface water can rapidly decrease from more than 30 to less than 10, due to large amount of freshwater inflow after heavy rain (Katano et al., 2012). Adaptation to those unavoidable environmental stress is crucial for the survival and growth of algae. It has been shown that exposure to elevated irradiance may cause photooxidative damage of Chattonella species (Warner and Madden, 2007; Mukai et al., 2018), and rapid decrease in salinity may affect their diel vertical migration (DVM) behavior and accumulation in surface water (Katano et al., 2012; Shikata et al., 2014). However, insights into the responses of Chattonella to rapid shifts of environmental factors remains largely unknown.

Photosynthesis is the basic and essential process for the growth, cell division, and other vital functions of all photosynthetic organisms (Baker, 2008; Schaum et al., 2017; Slattery et al., 2017). Thus, photosynthetic parameters have been widely used to reflect and monitor algal growth and health (Kruskopf and Flynn, 2010; Stirbet and Govindjee, 2011; Larkum et al., 2012). For example, the $\mathrm{F}_{\mathrm{v}} / \mathrm{F}_{\mathrm{m}}$ ratio, which reflects the efficiency of photochemical conversion of light energy, has been found to be significantly correlated to the growth rate 
and/or growth phase of phytoplankton species (Kruskopf and Flynn, 2010; Oukarroum, 2016), including Chattonella (Qiu et al., 2013; Qiu et al., 2016). Recently, the Chlorophyll a fluorescence transient (OJIP) test has become an important tool in monitoring the photosynthetic events and physiological state of plant and algae (Strasser et al., 2004; Kruskopf and Flynn, 2010). It has been proved that the OJIP analysis not only can reflect the impacts of various stresses to algae, but also can provide reliable interpretation for the mechanisms involved in the stress responses (Hockin et al., 2012; Żak and Kosakowska, 2015).

In this study, therefore, we investigated variations in OJIP parameters of C. marina var. antiqua grown under various culture conditions, i.e., short-term irradiance shifts, repeated irradiance shifts, and rapid salinity shifts at various temperatures. The objective of this study is to reveal the stress responses of Chattonella species to shifts of those environmental factors, from the viewpoint of its photosynthetic activity.

\section{MATERIALS AND METHODS}

\section{Species and general culture conditions}

An axenic strain of $C$. marina var. antiqua (NIES-1) was obtained from the National Institute of Environmental Studies (NIES, Japan). Stock cultures were maintained using modified SWM-3 medium (Yamasaki et al., 2007) adjusted to a salinity of 30 at $25^{\circ} \mathrm{C}$ under $110 \pm 10 \mu \mathrm{mol}$ photons $\mathrm{m}^{-2} \mathrm{~s}^{-1}$ of cool-white fluorescent illumination with a $14: 10 \mathrm{~h}$ light: dark cycle. Semicontinuous cultures of $C$. marina var. antiqua were conducted under the same conditions as stock culture. These cultures were diluted daily by fresh media to maintain a constant cell density $\left(8 \times 10^{3}\right.$ cells $\left.\mathrm{ml}^{-1}\right)$, and, after acclimation, a constant growth rate (0.59 \pm 0.08 div. $\left.\mathrm{d}^{-1}\right)$. Those cell suspensions were used for the following experiments.

\section{Effects of short-term irradiance shifts}

Effects of short-term irradiance shifts on OJIP parameters were assessed over the course of a day during the semicontinuous culture under the control irradiance (CI, i.e., $110 \pm 10 \mu \mathrm{mol}$ photons $\mathrm{m}^{-2} \mathrm{~s}^{-1}$ ). About $50 \mathrm{ml}$ cell suspension was incubated to a new $70 \mathrm{ml}$ sterile flask $(n=3)$ and then shifted from control irradiance to an elevated irradiance (EI) at $1100 \pm 50 \mu \mathrm{mol}$ photons $\mathrm{m}^{-2} \mathrm{~s}^{-1}$ from 11:00 (6 h after lights-on), and subsamples for OJIP test were taken at 15:00 (4 h after shift to EI). Subsequently, $30 \mathrm{ml}$ cell suspension exposed to EI were incubated to a new $70 \mathrm{ml}$ sterile flask $(\mathrm{n}=3$ ) and then shifted to CI for recovery, respectively. Samples to assess recovery of OJIP parameters were taken at 16:00 (1 $\mathrm{h}$ after recovery), 17:00, and 18:00. As the control, OJIP parameters of cell suspensions in the semicontinuous culture were measured at the necessary time points described as above.

\section{Effects of repeated irradiance shifts}

To assess effects of repeated exposure to elevated irradiance (EI), batch cultures of C. marina var. antiqua were started by inoculating cells suspension in semicontinuous culture into 70-ml sterile flask (Nunc; $n=3$ ) containing $50 \mathrm{ml}$ modified SWM-3 medium, at an initial cell density of $1 \times 10^{3}$ cells $\mathrm{ml}^{-1}$. C. marina var. antiqua was grown under the same conditions as stock culture, except the irradiance condition described as follows: (i) control, the irradiance was set at $110 \pm 10 \mu \mathrm{mol}$ photons $\mathrm{m}^{-2} \mathrm{~s}^{-1}$ during the 14-h light period (Fig. 1A); (ii) repeated exposure to elevated irradiance (REI), the irradiance was elevated to $1100 \pm 50 \mu \mathrm{mol}$ photons $\mathrm{m}^{-2} \mathrm{~s}^{-1}$ from 11:00 to $15: 00$, and was set at $110 \pm 10 \mu \mathrm{mol}$ photons $\mathrm{m}^{-2} \mathrm{~s}^{-1}$ during the rest times of the $14-\mathrm{h}$ light period (Fig. 1B). Batch cultures of C. marina var. antiqua were conducted for 7 days, and all flasks were gently mixed by hand twice a day. Measurement of cell number and OJIP test were conducted daily at 10:30 (4.5 h after the start of the photoperiod), and OJIP parameters in REI treatment were also measured at 15:00 (just after 4-h exposure to EI) and 18:00 (after 3-h recovery in CI).
(A) Dark
$\mathrm{Cl}$
Dark

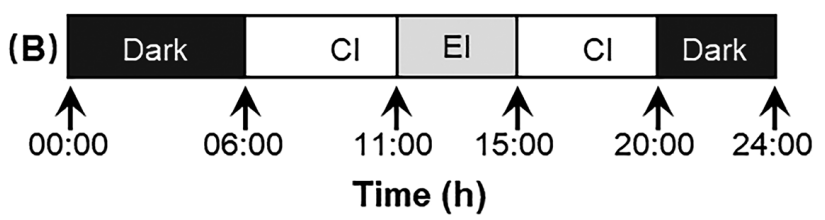

Fig. 1. Diagram showing the setting of light intensity for testing effects of repeated elevated irradiance (REI) exposure on the growth and OJIP-fluorescence parameters of Chattonella marina var. antiqua during batch cultures. CI: control irradiance at $110 \pm 10 \mu \mathrm{mol}$ photons $\mathrm{m}^{-2} \mathrm{~s}^{-1}$; EI: elevated irradiance at $1100 \pm 50 \mu \mathrm{mol}$ photons $\mathrm{m}^{-2} \mathrm{~s}^{-1}$.

\section{Combined effects of temperatures and rapid shifts of salinity}

To test the effects of rapid shifts in salinity at different temperatures, C. marina var. antiqua cells in semicontinuous culture were preconditioned to each temperature (i.e., 30,25 , or $20^{\circ} \mathrm{C}$ ) for a minimum of 2 weeks before experiment. Five test salinities (30, 25, 20, 15, and 10) of modified SWM-3 medium were adjusted by mixing the modified SWM-3 media of salinities 30 and 0 , accordingly. After acclimation, C. marina var. antiqua cells in semicontinuous were inoculated into 8-ml sterile culture tubes (Evergreen Scientific, Los Angeles, CA) containing $5 \mathrm{ml}$ of a prepared modified SWM-3 medium with different salinities, and grown under corresponding temperatures. The initial cell density was $1 \times 10^{3}$ cells $\mathrm{ml}^{-1}$, and other culture conditions (except temperature and salinity) were the same as those of stock cultures. Each experimental group had three replicates. Cultivations were conducted for 3 days, and cell growth was measured daily by in vivo fluorescence (model 10 AU-005-CE fluorometer; Turner Designs, Sunnyvale, CA). The OJIP test were conducted at the end of culti- 
vation (i.e., $72 \mathrm{~h}$ after the salinity shifts).

\section{OJIP test and calculation of growth rate}

Unless noted otherwise, OJIP tests were conducted at the same times between 10:00 (4 h after the start of the photoperiod) and 11:00 am to minimize effects of diel periodicity in algal physiological factors. The OJIP test was conducted using an AquaPen-C portable fluorometer (Photon Systems Instruments, Czech Republic). The AquaPen-C was set to maximum saturation pulse intensity of $3000 \mu \mathrm{mol}$ photon $\mathrm{m}^{-2} \mathrm{~s}^{-1}$ of red light $(625$ $\mathrm{nm}$ ) for $2 \mathrm{~s}$ and OJIP curves were recorded using the supplied FluorPen software (Photon Systems Instruments). The OJIP features of the fluorescence induction curve were defined following the equations described by Strasser et al. (2004).

The growth rate (GR, divisions $\mathrm{d}^{-1}$ ) were determined as GR $=\ln \left(N_{2} / \mathrm{N}_{1}\right) /\left[\ln (2) *\left(\mathrm{t}_{2}-\mathrm{t}_{1}\right)\right]$, where $N_{1}$ and $N_{2}$ are defined as values of cell densities or in vivo fluorescence at time $1\left(\mathrm{t}_{1}\right)$ and time $2\left(\mathrm{t}_{2}\right)$, respectively (Guillard, 1973). The maximum growth rate was determined as the maximum GR from 3 consecutive data points during the entire cultivation.

\section{Statistical analysis}

The experimental data were checked for assump- tions of homogeneity of variance across treatments using Levene's test, and data were normalized using square root or square arcsine transformation to meet the requirements of analysis of variance (ANOVA). For data of subsection 2.2, an independent sample t-test was used to test for differences between the irradiance shifts treatment and control groups. For data of subsection 2.3, one-way ANOVA followed by Dunnett's pairwise multiple comparison t-test was used to test differences between treatments and control. For data of subsections 2.4, two-way ANOVA was applied in analyzing the effects of temperature, salinity and their interactions on the growth and OJIP parameters. Once a significant interaction was detected, a simple effect analysis was conducted to examine the difference between various salinity shifts groups within each level of temperature. All statistical analyses were performed using SPSS Advanced Models 11.0J software (SPSS Japan, Tokyo, Japan).

\section{RESULTS}

\section{Effects of short-term irradiance shifts}

During the light period of experiment, the ranges of average $\mathrm{F}_{\mathrm{v}} / \mathrm{F}_{\mathrm{m}}$ ratio, $\mathrm{PI}_{\mathrm{ABS}}, \mathrm{ABS} / \mathrm{RC}, \mathrm{TRo} / \mathrm{RC}, \mathrm{ETo} / \mathrm{RC}$, and DIo/RC of C. marina var. antiqua grown at control irra-
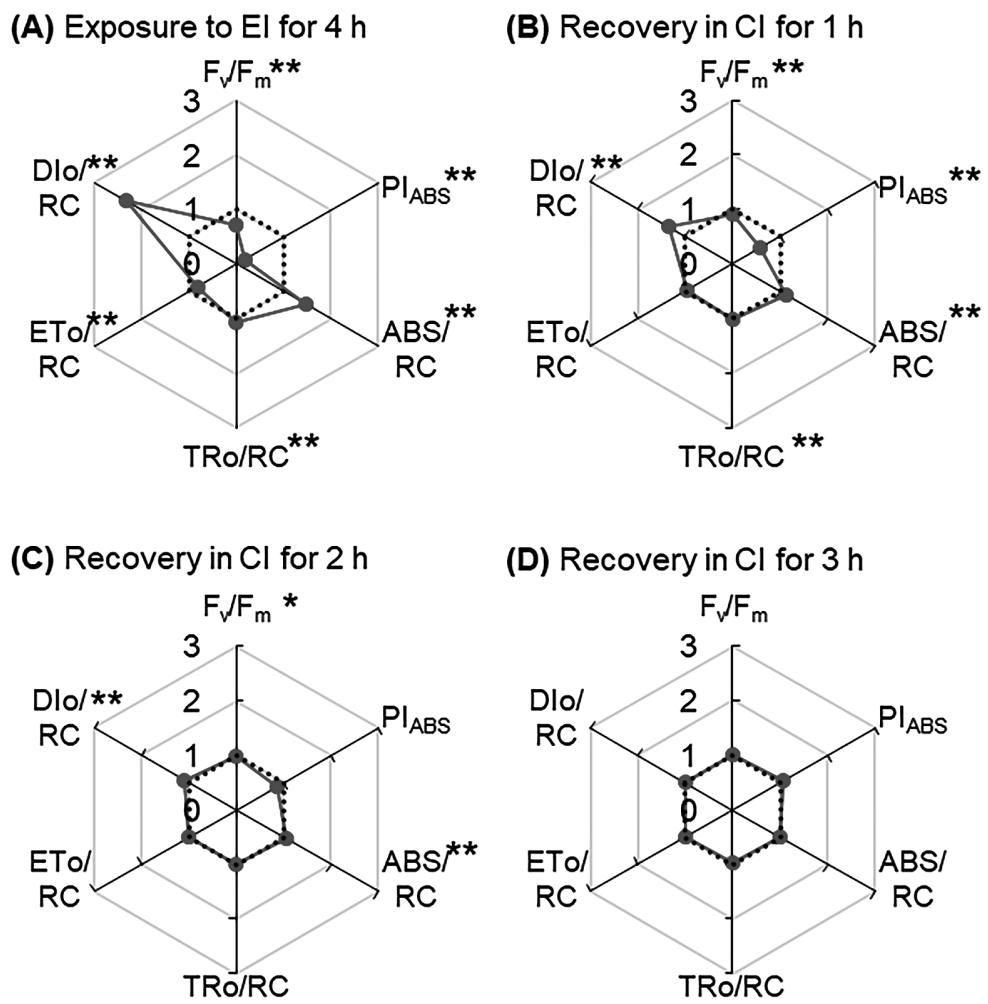

Fig. 2. Spider diagrams showing variations in OJIP-fluorescence parameters of Chattonella marina var. antiqua exposed to elevated irradiance (EI, $1100 \pm 50 \mu \mathrm{mol}$ photons $\mathrm{m}^{-2} \mathrm{~s}^{-1}$ ) for $4 \mathrm{~h}$ (A), and subsequently recovered at control irradiance (CI, $110 \pm 10 \mu \mathrm{mol}$ photons $\mathrm{m}^{-2} \mathrm{~s}^{-1}$ ) for $1 \mathrm{~h}(\mathrm{~B}), 2 \mathrm{~h}$ (C), and $3 \mathrm{~h}$ (D). Data of irradiance shifts treatment group (solid lines with circle symbol) are shown as the values after normalization to respective values obtained in the control (dotted lines). Asterisks following the parameter labels indicates significant between treatment and control ( $* p<0.05$; ** $p<0.01$ ). 
diance were $0.67-0.70,0.97-1.42,2.47-2.71,1.74-1.78$, $1.03-1.07$, and $0.73-0.94$, respectively. As shown in Fig. $2 \mathrm{~A}$, exposure to EI for $4 \mathrm{~h}$ significantly decreased the $\mathrm{F}_{\mathrm{v}} /$ $\mathrm{F}_{\mathrm{m}}$ ratio $\left(72 \%\right.$ of control), $\mathrm{PI}_{\mathrm{ABS}}$ (18\% of control), and $\mathrm{ETo} / \mathrm{RC}$ ( $82 \%$ of control), while increased the ABS/RC (145\% of control), TRo/RC (107\% of control), and DIo/ RC (234\% of control). When the EI exposed cells were shifted back to the CI, all the parameters derived from the OJIP analysis rapidly recovered to the level of those in the control group. The ETo/RC recovered within $1 \mathrm{~h}$ (Fig. 2B), the $\mathrm{PI}_{\mathrm{ABS}}$ and TRo/RC recovered within $2 \mathrm{~h}$ (Fig. $2 \mathrm{C}$ ), and the $\mathrm{F}_{\mathrm{v}} / \mathrm{F}_{\mathrm{m}}$ ratio, $\mathrm{ABS} / \mathrm{RC}$, and DIo/RC recovered within $3 \mathrm{~h}$ (Fig. 2D).

\section{Effects of repeated irradiance shifts}

Despite the irradiance conditions of batch cultures, C. marina var. antiqua cells began to grow well from day 1 and reached early stationary phase from day 4 onwards (Fig. 3A). There was no significant difference in the maximum growth rates of $C$. marina var. antiqua cultured in CI $\left(1.07 \pm 0.04\right.$ divisions $\left.\mathrm{d}^{-1}\right)$ and REI $(0.98$ \pm 0.04 divisions $\left.\mathrm{d}^{-1}\right)$. However, REI treatment significantly reduced the maximum cell densities of $C$. marina var. antiqua, which were decreased to $64 \%(p<0.01)$ of that in control cultures. As shown in Fig. 3B, the $\mathrm{F}_{\mathrm{v}} /$ $\mathrm{F}_{\mathrm{m}}$ ratio of C. marina var. antiqua was significantly decreased to $61-92 \%$ of that in control cultures after $4-\mathrm{h}$ EI exposure, and those inhibitions recovered to the level of control (97-101\%) at the next morning. The $\mathrm{PI}_{\mathrm{ABS}}$ of C. marina var. antiqua was significantly decreased to 5-60\% of that in control cultures after 4-h EI exposure, and those inhibitions recovered to the level of control (94-96\%) at the next morning at the exponential phase (i.e., day 1 to day 3, Fig. 3B). When the cultures reached stationary phase (i.e., from day 4 onwards), however, the inhibitions of $\mathrm{PI}_{\mathrm{ABS}}$ could not completely recover to the level of control (Fig. 3C).

\section{Effects of temperature and rapid shifts of salinity}

The maximum growth rates of $C$. marina var. antiqua grown at different combinations of temperature and salinity are shown in Fig. 4A. The highest maximum growth rate $\left(0.96 \pm 0.04\right.$ divisions $\left.\mathrm{d}^{-1}\right)$ was observed at $25^{\circ} \mathrm{C}$ and a salinity of 20 . Two-way ANOVA indicated significant effects of temperature, salinity shifts, and their interactions on the growth rate, $\mathrm{F}_{\mathrm{v}} / \mathrm{F}_{\mathrm{m}}$ ratio, and
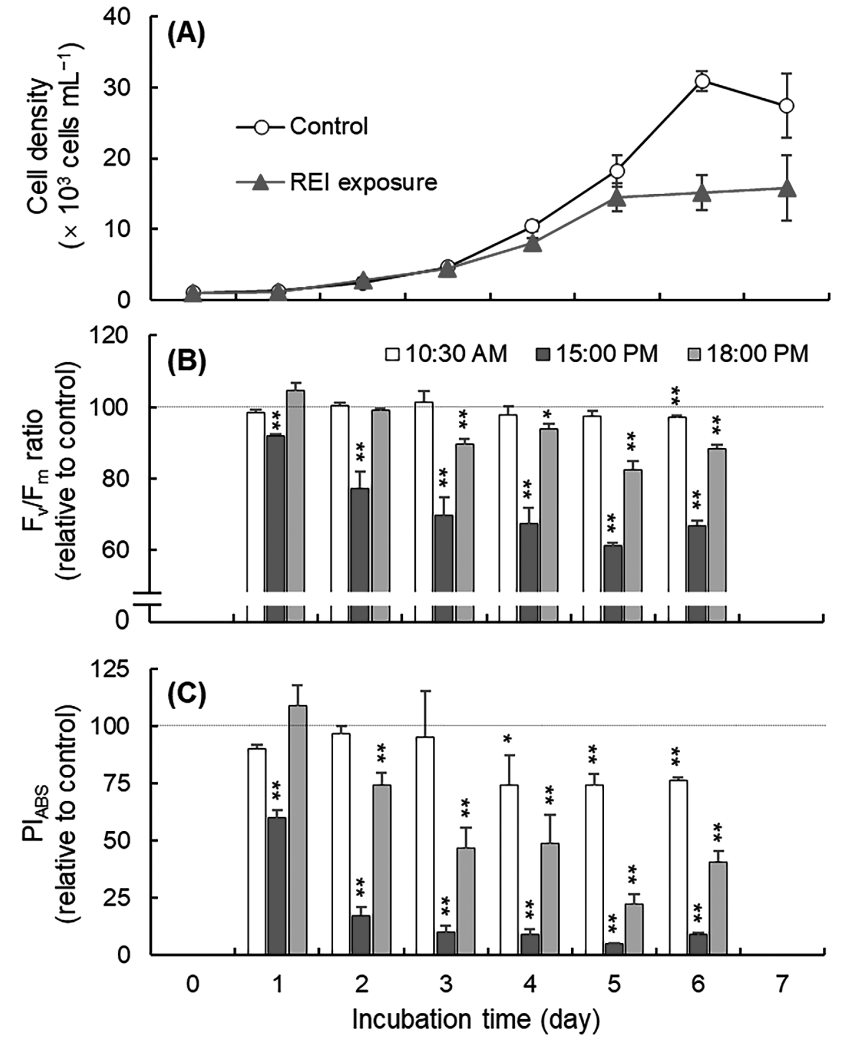

Fig. 3. Daily variations in cell density $(A), F_{v} / F_{m}$ ratio $(B)$ and $P_{A B s}$ (C) of Chattonella marina var. antiqua during batch cultures at different irradiance conditions. Control irradiance (CI): $110 \pm 10 \mu \mathrm{mol}$ photons $\mathrm{m}^{-2} \mathrm{~s}^{-1}$ during the 14 -h light period; REI: the irradiance was elevated to $1100 \pm 50 \mu \mathrm{mol}$ photons $\mathrm{m}^{-2} \mathrm{~s}^{-1}$ (EI) from 11:00 to 15:00, and was set at CI during the rest times of light period. OJIP parameters were measured at 10:30 (just before EI exposure), 15:00 (just after the 4-h exposure to EI), and 18:00 (3h after the end of EI exposure). Data of $\mathrm{F}_{\mathrm{v}} / \mathrm{F}_{\mathrm{m}}$ ratio and $\mathrm{PI}_{\mathrm{ABS}}$ are are mean $\pm \mathrm{SD}(\mathrm{n}=3)$, which are shown as the values after normalization to respective values obtained in the control (dotted lines). Asterisks indicates significant between treatment and control $(* p<0.05 ; * *<0.01)$.

$\mathrm{PI}_{\mathrm{ABS}}$ of C. marina var. antiqua at the $p<0.001$ level (Table 1). Therefore, simple effect analysis was conducted to examine the difference among salinity shifts within each level of temperature. At $30^{\circ} \mathrm{C}$, only the salinity shifts from 30 to 10 significantly decreased the maximum growth rate, $\mathrm{F}_{\mathrm{v}} / \mathrm{F}_{\mathrm{m}}$ ratio, and $\mathrm{PI}_{\mathrm{ABS}}$ of $C$.

Table 1. Summary of results of two-way ANOVA testing the effects of temperature, salinity shifts and their interaction on the maximum growth rate, $\mathrm{F}_{\mathrm{v}} / \mathrm{F}_{\mathrm{m}}$ ratio, and $\mathrm{PI}_{\mathrm{ABS}}$ of $C$. marina var. antiqua ${ }^{\mathrm{a}}$

\begin{tabular}{|c|c|c|c|c|c|c|c|c|c|c|c|c|c|}
\hline \multirow[b]{2}{*}{ Factors } & \multirow[b]{2}{*}{$d f$} & \multicolumn{4}{|c|}{ Maximum growth rate } & \multicolumn{4}{|c|}{$\mathrm{F}_{\mathrm{v}} / \mathrm{F}_{\mathrm{m}}$ ratio } & \multicolumn{4}{|l|}{$\mathrm{PI}_{\mathrm{ABS}}$} \\
\hline & & $\begin{array}{c}\text { Type } \\
\text { III-SS }\end{array}$ & Mean S & F-value & $p$-value & $\begin{array}{c}\text { Type } \\
\text { III-SS } \\
\end{array}$ & Mean S & F-value & $p$-value & $\begin{array}{c}\text { Type } \\
\text { III-SS }\end{array}$ & Mean S & F-value & $p$-value \\
\hline Intercept & 1 & $2.2 \mathrm{e}+01$ & $2.2 \mathrm{e}+01$ & $1.2 \mathrm{e}+04$ & $<0.001$ & $2.4 \mathrm{e}+01$ & $2.4 e+01$ & $2.0 \mathrm{e}+06$ & $<0.001$ & $2.3 e+02$ & $2.3 e+02$ & $8.8 \mathrm{e}+03$ & $<0.001$ \\
\hline Temperature & 2 & $6.9 \mathrm{e}-01$ & $3.4 \mathrm{e}-01$ & $1.9 \mathrm{e}+02$ & $<0.001$ & $5.0 \mathrm{e}-02$ & $2.5 \mathrm{e}-02$ & $2.0 \mathrm{e}+03$ & $<0.001$ & $3.6 \mathrm{e}+01$ & $1.8 \mathrm{e}+01$ & $7.1 \mathrm{e}+02$ & $<0.001$ \\
\hline Salinity & 4 & $8.2 \mathrm{e}-01$ & $2.1 \mathrm{e}-01$ & $1.1 \mathrm{e}+02$ & $<0.001$ & $3.3 e-03$ & $8.3 e-04$ & $6.7 e+01$ & $<0.001$ & $2.0 \mathrm{e}+00$ & $4.9 \mathrm{e}-01$ & $1.9 \mathrm{e}+01$ & $<0.001$ \\
\hline Interaction & 8 & $8.3 e-02$ & $1.0 \mathrm{e}-02$ & $5.8 e+00$ & $<0.001$ & $8.7 e-04$ & $1.1 \mathrm{e}-04$ & $8.8 e+00$ & $<0.001$ & $1.4 \mathrm{e}+00$ & $1.8 \mathrm{e}-01$ & $7.1 \mathrm{e}+00$ & $<0.001$ \\
\hline Error & 30 & $5.4 \mathrm{e}-02$ & $1.8 \mathrm{e}-03$ & & & $3.7 \mathrm{e}-04$ & $1.2 \mathrm{e}-05$ & & & $7.6 \mathrm{e}-01$ & $2.5 \mathrm{e}-02$ & & \\
\hline
\end{tabular}

${ }^{a} d f$ : degree of freedom; Type III-SS: Type III sum of squares; Mean S: mean square; bold value is statistically significant 
marina var. antiqua (Fig. 4). At $25^{\circ} \mathrm{C}$, the acute salinity shifts from 30 to 10 also tended to significantly decrease the maximum growth rate, $\mathrm{F}_{\mathrm{v}} / \mathrm{F}_{\mathrm{m}}$ ratio, and $\mathrm{PI}_{\mathrm{ABS}}$ (Fig. 4), and the acute salinity shifts from 30 to 20-25 tended to significantly increase the $\mathrm{PI}_{\mathrm{ABS}}$ (Fig. 4C). At $20^{\circ} \mathrm{C}$, acute salinity shifts from 30 to 10 or 15 tended to significantly decrease the maximum growth rate and $\mathrm{F}_{\mathrm{v}} /$ $\mathrm{F}_{\mathrm{m}}$ ratio of C. marina var. antiqua (Fig. $4 \mathrm{~A}$ and $\mathrm{B}$ ), while no significant differences were observed among their $\mathrm{PI}_{\mathrm{ABS}}$ values (Fig. 4C).
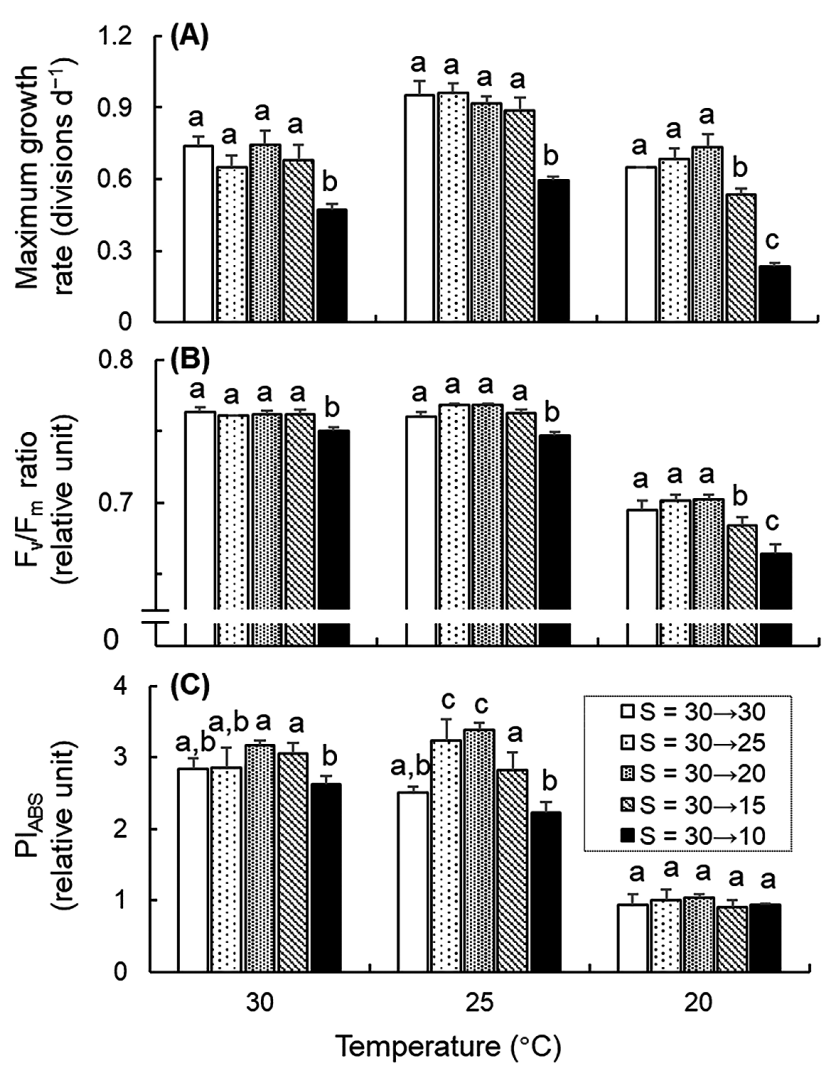

Fig. 4. Effects of rapid salinity shifts on the maximum growth rate (A), $\mathrm{F}_{\mathrm{v}} / \mathrm{F}_{\mathrm{m}}$ ratio (B) and $\mathrm{PI}_{\mathrm{ABS}}(\mathrm{C})$ of Chattonella marina var. antiqua grown at different temperatures. Data are mean $\pm \mathrm{SD}$ of triplicate measurements, and values not sharing a common letter are significantly different at $p<$ 0.05 .

\section{DISCUSSION}

Chlorophyll $a$ fluorescence transient (OJIP) analysis suggested that $C$. marina var. antiqua at exponential phase has relative strong capabilities to avoid impacts of environmental stress, such as rapid shifts to elevated irradiance or to low salinity. Those capabilities may contribute to maintaining a high photosynthetic activity and growth rate of cells grown at complex and volatile environment conditions, such as in the coastal waters during summer seasons.

Our results demonstrated that short-term exposure to light intensity of $1100 \mu \mathrm{mol}$ photons $\mathrm{m}^{-2} \mathrm{~s}^{-1}$ is strong enough to induce photoinhibition of $C$. marina var. antiqua, as indicated by the significant decreases in $\mathrm{F}_{\mathrm{v}} /$
$\mathrm{F}_{\mathrm{m}}$ ratio and $\mathrm{PI}_{\mathrm{ABS}}$ (Fig. $2 \mathrm{~A}$ ). When the amount of light exceeds that which can be used for photochemical energy transfer, the potential for irreversible photooxidative damage increases (Sirikhachornkit and Niyogi, 2010). However, our results suggested that $C$. marina var. antiqua may own strong capabilities to resist the potential damage induced high light intensity, as indicated by the rapid (within $3 \mathrm{~h}$ ) recovery of the photosynthetic parameters, after shifting back to CI (Fig. 2B-D). Similarly, Warner and Madden (2007) also reported that exposure to a high light intensity $\left(600 \mu \mathrm{mol}\right.$ photons $\mathrm{m}^{-2}$ $\mathrm{s}^{-1}$ for $1 \mathrm{~h}$ ) notably reduced the $\mathrm{F}_{\mathrm{v}} / \mathrm{F}_{\mathrm{m}}$ ratio of the $C$. $s u b$ salsa (raphidophyte), while the inhibited $\mathrm{F}_{\mathrm{v}} / \mathrm{F}_{\mathrm{m}}$ ratio could recover to normal within $6 \mathrm{~h}$ after shifting back to the low irradiance $\left(30 \mu \mathrm{mol}\right.$ photons $\left.\mathrm{m}^{-2} \mathrm{~s}^{-1}\right)$. It seems that Chattonella spp. have strong tolerance to high light intensity exposure.

Analysis of parameters derived from the OJIP curve also well supported the conclusion that Chattonella has strong tolerance to irradiance shifts (Fig. 2). Under EI exposure conditions, the increase in $\mathrm{ABS} / \mathrm{RC}$ could attribute to the decrease in active reaction centers and/ or in active $\mathrm{Q}_{\mathrm{A}}$ reducing centers (Strasser and Stirbet, 1998). The inhibition of re-oxidation of $\mathrm{Q}_{\mathrm{A}}^{-}$to $\mathrm{Q}_{\mathrm{A}}$ can increase the value of $\mathrm{TRo} / \mathrm{RC}$, in turn resulting in reduced electron transport per trapping, as indicated by the reduced ETo/RC (Strasser et al., 2000; Seepratoomrosh et al., 2016). The notably increased DIo/RC indicates an increased non-photochemical energy dissipation from the active RCs (Strasser et al., 2004). All these energy flux ratios supported that the photosynthetic efficiency was decreased due to EI exposure. However, rapid recovery of those parameters derived from the OJIP curve suggested that the regulate mechanisms are effective for acclimating to rapid changes in light intensity, which may give Chattonella cells some ecological advantages HABs.

It is well known that natural populations of some flagellates display diurnal vertical migration (DVM) behavior, which enable them to actively acquire light at surface layers and nutrients over a wide depth range (Watanabe et al., 1995; Shikata et al., 2015; Tilney et al., 2015). Because Chattonella cells tend to accumulated in the surface water during midday in summer (Watanabe et al., 1995), a strong tolerance to EI exposure is necessary for resisting the potential photooxidative damages. During the process of downward migration, the rapid recovery of photosynthetic activity may help Chattonella cells to store more energy and produce more organic matter for other vital functions. Those rapid photoprotective mechanisms may provide an explanation for the findings that Chattonella species can maximize photosynthesis and growth well under high light conditions (Warner and Madden, 2007; Qiu et al. 2013; Tilney et al., 2015).

During a batch culture, repeated EI exposure (REI, exposure to EI for $4 \mathrm{~h}$ per day) did not affect the maximum growth rates but significantly reduced the maximum cell density of $C$. marina var. antiqua (Fig. 3A). Similar growth curves of $C$. marina var. antiqua and $C$. 
subsalsa grown under elevated irradiances conditions have also been found by previous studies (Warner and Madden, 2007; Qiu et al., 2013; Tilney et al., 2015). The OJIP analysis of parameters suggests that the tolerance of C. marina var. antiqua to EI exposure was depended on their growth phases (Fig. 3). In the exponential growth phase, the inhibitions in $\mathrm{F}_{\mathrm{v}} / \mathrm{F}_{\mathrm{m}}$ ratio and $\mathrm{PI}_{\mathrm{ABS}}$ recovered to the level of control in the next morning, which may provide an explanation for the unaffected growth rate of $C$. marina var. antiqua cells in the REI group. These findings strongly suggested that the weak light intensity in morning and evening is important for the recovery from photoinhibition and consequent algal growth in actual environment. On the other hand, excessive light intensity can cause photooxidative stress in plants and algae, and eliminating those oxidative substances needs extra consumption of energy (Leeuwe et al., 2005; Mukai et al., 2018). Moreover, the reduced tolerance of $C$. marina var. antiqua in the stationary phase may result in an accumulation of photooxidative damage due to repeated EI exposure, which may further aggravate the extra energy consumption. Therefore, we inferred that the reduced EI-tolerance may partly contribute to the reduced maximum cell density of $C$. marina var. antiqua in exposure group.

The molecular mechanisms involved in the stresstolerance of Chattonella to EI are still unclear. In general, excessive light energy can increase the production of reactive oxygen species (ROS) and thereby cause oxidative stress in plants and algae (Leeuwe et al., 2005; Mukai et al., 2018). Thus, the 2-Cys peroxiredoxin (Prx), which is a highly expressed antioxidant in $C$. marina var. antiqua in the exponential phase, has been considered to play important roles in protecting cells against photooxidative damage and maintaining a high growth rate (Qiu et al., 2013; Mukai et al., 2018; Mukai et al., 2019). Indeed, the transcript expression levels of 2-Cys Prx in Chattonella cells was induced by EI exposure in batch cultures (Mukai et al., 2018), and its protein expression levels exhibited significant positive correlations with the growth rate and $\mathrm{F}_{\mathrm{v}} / \mathrm{F}_{\mathrm{m}}$ ratio of Chattonella cells during a field HAB (Qiu et al., 2016). In addition, our previous study also found a significant decrease in protein expression level of 2-Cys Prx in $C$. marina var. antiqua at the later stationary phase (Qiu et al., 2013). This finding may partly explain the reduced tolerance of $C$. marina var. antiqua to EI exposure, when the cells reached stationary phase.

The growth rates of $C$. marina var. antiqua at different combinations of temperature and salinity (Fig. 4 A) agreed well with those reported by previous studies (Yamaguchi et al., 1991; Yamatogi et al., 2006). For example, Yamaguchi et al. (1991) reported that $C$. marina var. antiqua can grow at temperatures from 15 to $30^{\circ} \mathrm{C}$ and salinity from 10 to 35 , with an maximal growth rates of 0.97 divisions $\mathrm{d}^{-1}$ (at the combination of $25^{\circ} \mathrm{C}$ and 25). Relative high growth rates (0.65-0.96 divisions $\left.\mathrm{d}^{-1}\right), \mathrm{F}_{\mathrm{v}} / \mathrm{F}_{\mathrm{m}}$ ratios $(0.76-0.77)$, and $\mathrm{PI}_{\mathrm{ABS}}(2.5-$ 3.4) were observed within the temperature range of $25-30{ }^{\circ} \mathrm{C}$ and salinity range of $15-30$. Those finding are consistent with the phenomenon that dense blooms (>1000 cells $\mathrm{ml}^{-1}$ ) of $C$. marina var. antiqua often occurred at the temperatures of $25-33^{\circ} \mathrm{C}$ in coastal areas of Japan (Yamaguchi et al., 1991; Yamatogi et al., 2006; Katano et al., 2012; Qiu et al., 2016). However, the surface salinity sometimes suddenly decreased to $<10$ as a consequence of freshwater input from rainfall during Chattonella blooms (Katano et al., 2012; Katano et al., 2014). Our results showed that the acute salinity shifts from 30 to 10 significantly decreased the maximum growth rate, $\mathrm{F}_{\mathrm{v}} / \mathrm{F}_{\mathrm{m}}$ ratio, and $\mathrm{PI}_{\mathrm{ABS}}$ of $C$. marina var. antiqua. Some previous studies have found that Chattonella cells moves to avoid water with low salinity (Katano et al., 2012; Katano et al., 2014; Shikata et al., 2014). Thus, our finding, together with those field observations, suggested that salinity shifts may play important roles in regulating the bloom dynamics of Chattonella.

In summary, our results indicated that the OJIP-test can provide reliable interpretation for stress responses of Chattonella spp. to rapid shifts of environmental factors. Among the parameters derived from the OJIP-test, the $\mathrm{PI}_{\mathrm{ABS}}$ is the most integrated and sensitive one for reflecting the photosynthetic events and physiological state of Chattonella. Nevertheless, molecular mechanisms involved in the regulation of OJIP transients in Chattonella is still largely unknown. Further works are clearly needed to investigate variations in gene and protein expressions of OJIP transients in Chattonella cells at various environmental stress, in order to promote our understanding of their adaptation mechanisms to changed environmental factors.

\section{AUTHOR CONTRIBUTIONS}

X. Qiu designed and carried out experiments, and wrote the paper. M. Wu and K. Mukai carried out experiments and data analysis. Y. Shimasaki designed the study. Y. Oshima supervised the work. All authors assisted in editing of the manuscript and approved the final version.

\section{ACKNOWLEDGEMENTS}

This study was supported by the Japan Society for the Promotion of Science Postdoctoral Fellowship for Foreign Researchers (Grant No. P12405) and a scientific research foundation for Jinshan Distinguished Professors, Jiangsu University (Grant No. 4111370002).

\section{REFERENCES}

Baker, N. R. 2008 Chlorophyll fluorescence: a probe of photosynthesis in vivo. Annual Review of Plant Biology 59: 89-113

García-Mendoza, E., Cáceres-Martínez, J., Rivas, D., Fimbres-Martinez, M., Sánchez-Bravo, Y., Vásquez-Yeomans, R., and Medina-Elizalde, J. 2018 Mass mortality of cultivated northern bluefin tuna Thunnus thynnus orientalis associated with Chattonella species in Baja California, Mexico. Frontiers in Marine Science $\mathbf{5}$

Guillard, R. (1973). Division rates. In Handbook of Phycological Methods (Stein, J. R., editor) Cambridge University Press, Cam- 
bridge, UK 289-312

Hockin, N. L., Mock, T., Mulholland, F., Kopriva, S., and Malin, G. 2012 The response of diatom central carbon metabolism to nitrogen starvation is different from that of green algae and higher plants. Plant Physiology 158: 299-312

Imai, I. and Yamaguchi, M. 2012 Life cycle, physiology, ecology and red tide occurrences of the fish-killing raphidophyte Chattonella. Harmful Algae 14: 46-70

Katano, T., Yoshida, M., Yamaguchi, S., Yoshino, K., Hamada, T., Koriyama, M., and Hayami, Y. 2014 Effect of nutrient concentration and salinity on diel vertical migration of Chattonella marina (Raphidophyceae). Marine Biology Research 10: 1007-1018

Katano, T., Yoshino, K., Matsubara, T., and Hayami, Y. 2012 Wax and wane of Chattonella (Raphidophyceae) bloom with special reference to competition between Skeletonema (Bacillariophyceae) in the Ariake Sea, Japan. Journal of Oceanography $\mathbf{6 8}$ : 497-507

Kruskopf, M. and Flynn, K. J. 2010 Chlorophyll content and fluorescence responses cannot be used to gauge reliably phytoplankton biomass, nutrient status or growth rate. New Phytologist 169: 525-536

Larkum, A. W. D., Douglas, S., and Raven, J. A. (2012). Photosynthesis in algae. Springer Science \& Business Media, Netherlands

Leeuwe, M. A. v., Sikkelerus, B. v., Gieskes, W. W. C., and Stefels, J. 2005 Taxon-specific differences in photoacclimation to fluctuating irradiance in an Antarctic diatom and a green flagellate. Marine Ecology Progress Series 288: 9-19

Marshall, J. and Hallegraeff, G. 1999 Comparative ecophysiology of the harmful alga Chattonella marina (Raphidophyceae) form South Australian and Japanese waters. Journal of Plankton Research 21: 1809-1822

Mukai, K., Shimasaki, Y., Qiu, X., Kato-Unoki, Y., Chen, K., Khanam, M. R. M., and Oshima, Y. 2019 Effects of light and hydrogen peroxide on gene expression of newly identified antioxidant enzymes in the harmful algal bloom species Chattonella marina. European Journal of Phycology: DOI: 10.1080/09670262.0 9672019.01576062

Mukai, K., Teramoto, A., Qiu, X., Shimasaki, Y., Kato-Unoki, Y., Lee, J. M., Mizoguchi, N., Khanam, M. R. M., Satone, H., Tatsuke, T., Kusakabe, T., and Oshima, Y. 2018 Gene structure and cDNA sequence of 2-Cys peroxiredoxin in the harmful algal bloom species Chattonella marina and its gene transcription under different light intensities. European Journal of Phycology $\mathbf{5 3}$ : 29-38

Nakamura, Y. 1985 Kinetics of nitrogen- or phosphorus-limited growth and effects of growth conditions on nutrient uptake in Chattonella antiqua. Journal of Oceanography 41: 381-387

Oukarroum, A. 2016 Change in photosystem II photochemistry during algal growth phases of Chlorella vulgaris and Scenedesmus obliquus. Curr Microbiol 72: 692-699

Pérez-Morales, A., Band-Schmidt, C. J., and Martínez-Díaz, S. F. 2017 Mortality on zoea stage of the Pacific white shrimp Litopenaeus vannamei caused by Cochlodinium polykrikoides (Dinophyceae) and Chattonella spp. (Raphidophyceae). Marine Biology 164: 57

Park, B. S., Joo, J.-H., Baek, K.-D., and Han, M.-S. 2016 A mutualistic interaction between the bacterium Pseudomonas asplenii and the harmful algal species Chattonella marina (Raphidophyceae). Harmful Algae 56: 29-36

Qiu, X., Mukai, K., Shimasaki, Y., Tsuyama, M., Matsubara, T., Nakajima, Y., Honjo, T., and Oshima, Y. 2016 Potential maximum quantum yield of photosystem II reflects the growth rate of Chattonella marina in field bloom samples. Journal of the Faculty of Agriculture, Kyushu University 61: 331-335

Qiu, X., Shimasaki, Y., Tsuyama, M., Yamada, T., Kuwahara, R., Kawaguchi, M., Honda, M., Gunjikake, H., Tasmin, R., and Shimizu, M. 2013 Growth-phase dependent variation in photosynthetic activity and cellular protein expression profile in the harmful raphidophyte Chattonella antiqua. Bioscience, biotechnology, and biochemistry 77: 46-52.
Qiu, X., Shimasaki, Y., Yoshida, Y., Matsubara, T., Yamasaki, Y., Kawaguchi, M., Honda, M., Mouri, K., Nakajima, Y., and Tasmin, R. 2014 Allelopathic Effects of Skeletonema spp. May Influence Interspecific Competition and Bloom Formation of $\mathrm{Co}-$ occurring Harmful Flagellates. Journal of the Faculty of Agriculture, Kyushu University 59: 373-382

Qiu, X., Yamasaki, Y., Shimasaki, Y., Gunjikake, H., Matsubara, T., Nagasoe, S., Etoh, T., Matsui, S., Honjo, T., and Oshima, Y. 2011 Growth interactions between the raphidophyte Chattonella antiqua and the dinoflagellate Akashiwo sanguinea. Harmful Algae 11: 81-87

Schaum, C. E., Barton, S., Bestion, E., Buckling, A., Garcia-Carreras, B., Lopez, P., Lowe, C., Pawar, S., Smirnoff, N., Trimmer, M., and Yvon-Durocher, G. 2017 Adaptation of phytoplankton to a decade of experimental warming linked to increased photosynthesis. Nature Ecology \& Evolution 1: 0094

Seepratoomrosh, J., Pokethitiyook, P., Meetam, M., Yokthongwattana, K., Yuan, W., Pugkaew, W., and Kangvansaichol, K. 2016 The effect of light stress and other culture conditions on photoinhibition and growth of Dunaliella tertiolecta. Applied Biochemistry and Biotechnology 178: 396-407

Shikata, T., Matsunaga, S., Nishide, H., Sakamoto, S., Onistuka, G., and Yamaguchi, M. 2015 Diurnal vertical migration rhythms and their photoresponse in four phytoflagellates causing harmful algal blooms. Limnology \& Oceanography 60: 1251-1264

Shikata, T., Sakamoto, S., Onitsuka, G., Aoki, K., and Yamaguchi, M. 2014 Effects of salinity on diel vertical migration behavior in two red-tide algae, Chattonella antiqua and Karenia mikimotoi. Plankton and Benthos Research 9: 42-50

Sirikhachornkit, A. and Niyogi, K. K. (2010). Antioxidants and photo-oxidative stress responses in plants and algae. In The Chloroplast: Basics and Applications (Rebeiz, C. A., Benning, C., Bohnert, H. J., Daniell, H., Hoober, J. K., Lichtenthaler, H.K., Portis, A. R., \& Tripathy, B.C., editors) Springer Netherlands, Dordrecht 379-396

Slattery, R. A., VanLoocke, A., Bernacchi, C. J., Zhu, X.-G., and Ort, D. R. 2017 Photosynthesis, light use efficiency, and yield of reduced-chlorophyll soybean mutants in field conditions. Frontiers in Plant Science 8: 549

Stirbet, A. and Govindjee 2011 On the relation between the Kautsky effect (chlorophyll a fluorescence induction) and Photosystem II: Basics and applications of the OJIP fluorescence transient. Journal of Photochemistry and Photobiology B: Biology 104: 236-257

Strasser, R. J., Srivastava, A., and Tsimilli-Michael, M. (2000). The fluorescence transient as a tool to characterize and screen photosynthetic samples. In Probing Photosynthesis: Mechanisms, Regulation and Adaptation (Yunus, M., Pathre, U., \& Mohanty, P., editors) CRC press, London and New York 445-483

Strasser, R. J. and Stirbet, A. 1998 Heterogeneity of photosystem II probed by the numerically simulated chlorophyll a fluorescence rise (O-J-I-P). Mathematics and Computers in Simulation 48: $3-9$

Strasser, R. J., Tsimilli-Michael, M., and Srivastava, A. (2004) Analysis of the chlorophyll a fluorescence transient. In Chlorophyll a Fluorescence: A Signature of Photosynthesis (Papageorgiou, G. C. \& Govindjee, editors) Springer Netherlands, Dordrecht 321-362

Tilney, C. L., Hoadley, K. D., and Warner, M. E. 2015 Comparing the diel vertical migration of Karlodinium veneficum (dinophyceae) and Chattonella subsalsa (Raphidophyceae): PSI photochemistry, circadian control, and carbon assimilation. Journal of Photochemistry and Photobiology B: Biology 143 107-119

Warner, M. E. and Madden, M. L. 2007 The impact of shifts to elevated irradiance on the growth and photochemical activity of the harmful algae Chattonella subsalsa and Prorocentrum minimum from Delaware. Harmful Algae 6: 332-342

Watanabe, M., Kohata, K., Kimura, T., Takamatsu, T., Yamaguchi, S.-i., and Ioriya, T. 1995 Generation of a Chattonella antiqua bloom by imposing a shallow nutricline in a mesocosm. Limnology \& Oceanography 40: 1447-1460 
Yamaguchi, M., Imai, I., and Honjo, T. 1991 Effects of temperature, salinity and irradiance on the growth rates of the noxious red tide flagellates Chattonella antiqua and C. marina (Raphidophyceae). Nippon Suisan Gakkaishi 57: 1277-1284 (in Japanese with English abstract)

Yamasaki, Y., Nagasoe, S., Matsubara, T., Shikata, T., Shimasaki, Y., Oshima, Y., and Honjo, T. 2007 Allelopathic interactions between the bacillariophyte Skeletonema costatum and the raphidophyte Heterosigma akashiwo. Marine Ecology Progress Series 339: 83-92
Yamatogi, T., Sakaguchi, M., Iwataki, M., and Matsuoka, K. 2006 Effects of temperature and salinity on the growth of four harmful red tide flagellates occurring in Isahaya Bay in Ariake Sound, Japan. Nippon Suisan Gakkaishi 72: 160-168 (in Japanese with English abstract)

Żak, A. and Kosakowska, A. 2015 The influence of extracellular compounds produced by selected Baltic cyanobacteria, diatoms and dinoflagellates on growth of green algae Chlorella vulgaris. Estuarine, Coastal and Shelf Science 167: 113-118 